\title{
Effect of Nutritive and Nonnutritive Sweeteners on the Quality of Biscuits
}

\author{
Sally S. El-Sayed -Neveen F. Agamy 1
}

\begin{abstract}
Biscuits were prepared by replacing sucrose with dietetic sweeteners fructose, sorbitol, mannitol and stevia. Physical studies of biscuits revealed that replacement of sucrose with mannitol decreased greatly the width from $5.10 \mathrm{~cm}$ to reach $4.95 \mathrm{~cm}$. The thickness was increased from $0.40 \mathrm{~cm}$ in $T_{1}$ (sucrose) to $0.48 \mathrm{~cm}$ in $T_{5}$ (sorbitol). Maximum spread factor $(13.15 \mathrm{~cm})$ was obtained in $T_{1}$ (sucrose), while the lowest spread factor was $9.71 \mathrm{~cm}$ in $T_{5}$ (sorbitol). Sensory evaluation of the biscuits was evaluated at different time of storage (30, 60 and 90 days) to find the best treatment for commercialization. The results pertaining to sensory evaluation of biscuits indicated that the color, odor, texture and after taste gave the best score in $T_{1}$ (sucrose) at 0 days and the taste have its high score after 30 days of storage, while the worst score of taste, odor and texture was in $T_{2}$ (fructose) after 90 and 30 days of storage. The worst score in color and after taste was in $T_{4}$ (mannitol) and $T_{3}$ (stevia), respectively after 60 and 90 days of storage. The chemical analysis of biscuits showed moisture, crude protein, crude fat, ash and carbohydrates contents were ranging from $3.17-4.53 \%, 6.619-6.769 \%$, $16.90-17.95 \%, 0.60-0.97 \%$ and $71.51-70.17 \%$, respectively. The replacement of sucrose with dietetic sweeteners decreased the calorific value. Highest calorific value $(474.67 \mathrm{Kcal} / 100 \mathrm{~g})$ was observed in $T_{1}$ (sucrose), while the lowest calorific value $(459.54 \mathrm{Kcal} / 100 \mathrm{~g})$ was attained by $T_{3}$ (stevia).
\end{abstract}

Key Words: biscuits; Quality; Sweeteners; Dietetic; Storage.

\section{INTRODUCTION}

It was found that 180 million adult use products with low calorie. Consumers often select these foods and beverages because they want the taste of sweetness without added calories or because they want to reduce the risk of tooth decay. The dietary options that such products provide may be especially helpful in the management of obesity or diabetes mellitus, thus there is an increasing interest in low-calorie foods and beverages (Parpinello, et al, 2001).

Biscuit is the most popular bakery product consumed by nearly all levels of society. This is mainly due to its ready to eat nature, good nutritional quality, availability in different varieties, affordable cost and long shelf life (Causavin and Young, 2006). Short dough biscuits are products made from soft and weak wheat flours. They are characterized by a formula high in sugar and shortening. Sucrose performs many important roles in baking. It provides moisture and tenderness, liquefies when it bakes, increases the shelf-life of finished products, caramelizes at high temperatures, and, of course, adds sweetness. Diets high in sucrose may cause an increase in obesity rates or other chronic conditions e.g., hyperlipidemia, diabetes, dental caries and behavioral disorders (Ebbeling, et al, 2002).

The one way to control the consumption of sucrose is to replace it by low absorption sweeteners as fructose, polyols or nonnutritive sweetener as stevia (natural nonnutritive sweetener). Fructose and Sugar alcohols such as sorbitol, mannitol, are used in special dietary foods as a bulking agent and humectant with sweet taste (Francis, 2000).

Fructose is absorbed more slowly than glucose in the bloodstream. Unlike glucose, fructose is metabolized in the liver, meaning it does not require a large initial insulin response to move from the blood directly into the cells for metabolism. For this reason, some diabetics' patients found it useful in controlled amounts. Polyols and fructose can be used in Sugar-free chewing gums, candies, frozen desserts and baked goods (Butt, et al, 2002).

The absorption of polyols (sorbitol and mannitol) in our body is very slow and incomplete, so the energy absorbed is less as compared to energy absorbed in complete metabolism of polyols. These also do not cause rapid increase in blood glucose level. This is the reason; polyols are used in diabetic and dietetic biscuits and cookies (Warshaw and Powers, 1999).

Interest has been rekindled in more recent years, especially in the developed world where diet conscious consumers seek a natural low-calorie sweetener as an alternative to chemical sweeteners (Strauss, 1995).

There was an herbal supplement, stevia, used as a natural nonnutritive sweetener. Stevia, is a shrimp belongs to the family asteraccae, genus stevia and species rebaudiana. The other names of stevia are sweet leaf, honey leaf, sweet herb, honey yerba. Stevia is extensively grown in places like Brazil, Paraguay, Central America, Israel, but is a native to Paraguay (Sharma, et al, 2006).

Stevioside, a white crystalline compound isolated from stevia is 100 to 300 times sweeter than table sugar. It is used for the treatment of various conditions such as cancer, diabetes, obesity, dental cavities, hypertension, fatigue, depression, and yeast infection. It possesses hypoglycemic, hypotensive, vasodilation, taste improving, sweetening, antifungal, anti-viral, anti-inflammatory, anti-bacterial properties

\footnotetext{
${ }^{1}$ Nutrition. Dept., High Institute of Public Health,

Alexandria University, Alexandria, Egypt

Received Febuary 20, 2013, Accepted March 30, 2013
} 
and increases urination function of the body. It has been found to be non-toxic, non-addictive, non-carcinogenic, nonmutagenic and is devoid of genotoxic effect. It does not affect blood sugar level hence safe for diabetics (Alan, 2002).

Stevia sweeteners are heat stable to $200^{\circ} \mathrm{C}$, acid stable and do not ferment, making them suitable for use in a wide range of products including baked/cooked foods (Ikran, et al, 1993).

Therefore, the purpose of this study is to replace sucrose in biscuits with fructose, sorbitol, mannitol, and stevia, keeping in mind the improvement of the general quality of biscuits manufacturing.

\section{MATERIALS AND METHODS}

\section{Procurement of raw material:}

Commercial flour was obtained from flour Land Company in Alexandria. Different sweeteners i.e. fructose, sorbitol, mannitol and stevia were obtained from the local market. The basic recipe of biscuits is illustrated in Table 1.

\section{Preparation of biscuits:}

The biscuits were manufactured on a semi-commercial scale, employing the recipe of Candy factory for sweets, biscuits and chocolate in Alexandria. (Table 1)

In the formulation of biscuits according to the sweetening power of sweeteners used, sucrose was replaced with different sweeteners e.g. $150 \mathrm{~g}$ fructose $\left(\mathrm{T}_{2}\right), 3 \mathrm{~g}$ stevia $\left(\mathrm{T}_{3}\right), 400 \mathrm{~g}$ mannitol $\left(\mathrm{T}_{4}\right)$ and $400 \mathrm{~g}$ sorbitol $\left(\mathrm{T}_{5}\right)$.

All basic ingredients were weighted accurately. All ingredients were mixed except flour and aerating chemical, mixing time was $15 \mathrm{~min}$. The flour and aerating chemicals then added and mixed until dough acquires the desired consistency. Dough produced on the table and by using forcing roll it produced a thick sheet, evenly reduced this thick sheet in progressive steps to a desired thickness which suitable for baking the biscuits. The desired shapes (circle) were cut out and placed in the baking oven for $20 \mathrm{~min}$ in a proper distance at $240^{\circ} \mathrm{F}$. After baking; the biscuit was cooled at room temperature and packed in glass boxes and stored at room temperature for $0,30,60,90$ days for further studies.

\section{Analysis of biscuits}

Physical analysis: The biscuits were analyzed for width, thickness and spread factor according to the method described in AACC (2000). For that purpose, six cookies were placed horizontally and vertically to calculate the thickness and width, respectively. Spread factor was calculated according to the formula i.e. Spread Factor $=(\mathrm{W} / \mathrm{T})$

Chemical analysis: The biscuits were analyzed for moisture, crude protein, crude fat, ash contents according to the methods described in AOAC (1995). Carbohydrate content was calculated using the following equation: carbohydrate $\%=100-$ (Crude protein $\%+$ Crude fat $\%+$ Ash $\%+$ Moisture \%), which described by Egan, et al, (1981).

Sensory evaluation: The biscuits prepared by different type of sweeteners were evaluated for their sensory characteristics: color, taste, odor, texture and after taste after $0,30,60$, and 90 days of storage by taste panels consisting of fifteen judges.

The judges included the professors, staff and senior research of the Nutrition Department of High Institute of Public Health, Alexandria University. They were asked to score as rating $1-5$ (optimum $=5$, very poor $=1$ ) all samples of biscuits were given different code letters according to the procedure described by Meilgaard, et al, (2007).

Calorific value calculation: the calorific value of biscuits was calculated according to the formula i.e. Energy value of food $(\mathrm{Kcal} / 100 \mathrm{~g})=(\%$ available carbohydrates $\mathrm{x} 4)+(\%$ protein $\times 4)+(\%$ fat $\times 9)$, which described in AOAC (1995)

\section{Table 1. Basic recipe of biscuits}

\begin{tabular}{lcc}
\hline Ingredients & Weight in grams & \% \\
\hline Flour & 1000 & 58.428 \\
Sucrose & 280 & 16.36 \\
Shortening & 120 & 7.01 \\
Ammonium bicarbonate & 16 & 0.935 \\
Sodium bicarbonate & 4 & 0.23 \\
Sodium metabisulphate & 0.1 & 0.005 \\
Dried milk & 40 & 2.34 \\
Salt & 0.3 & 0.02 \\
Lecthin & 0.5 & 0.029 \\
Vanilia & 0.6 & 0.035 \\
Water & 250 & 14.61 \\
\hline
\end{tabular}


Statistical analysis: All statistical analysis were done using two tailed tests and alpha error of 0.05 . $\mathrm{P}$ value equals to or less than 0.05 was considered to be significant. After data were collected it was revised, coded and fed to statistical software SPSS version 16. The given graphs were constructed using Microsoft excel software.

\section{RESULTS AND DISCUSSIONS}

Physical analysis: The results pertaining to physical tests of biscuits are presented in Table 2. It showed that the mean value of width ranging from $5.10 \mathrm{~cm}$ in $\mathrm{T}_{1}$ (sucrose) to 4.43 $\mathrm{cm}$ in $\mathrm{T}_{4}$ (mannitol). The width of biscuits showed decrease in using dietetic sweeteners more than using of sucrose. (Table 2).

Our results revealed that there were significant differences in the mean value of width $(\mathrm{cm})$ in all biscuits treatments. The highest mean value of width was $5.10 \mathrm{~cm}$ which was detected in $T_{1}$ (sucrose). The biscuits which were treated with stevia $\left(\mathrm{T}_{3}\right)$ and sorbitol $\left(\mathrm{T}_{5}\right)$ were equal in their width $(4.48 \mathrm{~cm})$. The results of Tanya, (2006) was in agreement with our results which reported that the width of biscuits with $100 \%$ fructose value $(4.95 \mathrm{~cm})$ were smaller than those of $100 \%$ sucrose, and reported that fructose dissolves more completely prior to baking, so additional dissolution does not occur during baking, and therefore its ability to spread is reduced.

The thickness of biscuits increased with the treatment of sorbitol $\left(\mathrm{T}_{5}\right)$ to reach $0.48 \mathrm{~cm}$. Biscuits treated with stevia $\left(\mathrm{T}_{3}\right)$ and mannitol $\left(\mathrm{T}_{4}\right)$ were $0.45 \mathrm{~cm}$ and the lowest mean value of thickness was $0.40 \mathrm{~cm}$ which was observed in $\mathrm{T}_{1}$ (sucrose) and $\mathrm{T}_{2}$ (fructose). Treating biscuits with different types of sweeteners showed insignificant differences in thickness $(\mathrm{cm})$. Our results were supported by the results of Manohar and Rao, (1997) which also observed that increasing the amount of sugar resulted in an increase in biscuit diameter after baking.
Also, the results of Curley and Hoseney, (1984) showed that the diameter and height of cookies produced from sucrose and fructose gradually decreased with increasing fructose percentages, while cookie thickness increased up to $50 \%$.

The spread factor decreased greatly in T5 (sorbitol). Results revealed that there were insignificant differences of spread factor in all treatments of biscuits. The highest mean value of spread factor was $13.15 \mathrm{~cm}$ which was detected in T1 (sucrose), while T5 (sorbitol) showed the lowest value $(9.71 \mathrm{~cm})$, and the other treatments ranging between them. The results obtained could be compared with those of Siddique, (1995) who reported that use of artificial sweeteners in biscuits decreased the width and thickness of biscuits irrespective of the concentration of the sweeteners. However, the spread factor of biscuits increased progressively with the increase in concentration of sweeteners.

It can also be supported through the studies of Shafiq, (1999) who observed a decreasing trend in width of biscuits with increasing levels of dextrose and hydrol, while use of golden syrup first increased then decreased the width of biscuits.

Thickness of cookies was increased by increasing level of dextrose and decreased by increased level of hydrol and golden syrup. Spread factor was decreased by increasing levels of dextrose while increased with increasing levels of golden syrup and hydrol.

Chemical analysis: according to Table (3) the chemical analysis of biscuits showed that there were nonsignificant changes in moisture, protein, fat, ash and carbohydrates contents. Although, the study of Zarina, et al, (2010) reported that there were significant change in moisture content from biscuits treated with $100 \%$ sucrose which had the lowest score compared to biscuits with $100 \%$ xylitol which had the highest score.

Table 2. Effect of different types of sweetener treatments of biscuits on the mean value of width $(\mathrm{cm})$, thickness $(\mathrm{cm})$ and spread factor $(\mathrm{cm})$

\begin{tabular}{cccc}
\hline Treatments & $\begin{array}{c}\text { Width } \\
(\mathbf{c m})\end{array}$ & $\begin{array}{c}\text { Thickness } \\
(\mathbf{c m})\end{array}$ & $\begin{array}{c}\text { Spread factor } \\
(\mathbf{c m})\end{array}$ \\
\hline $\mathrm{T}_{1}$ & $5.10 \pm 0.08$ & $0.40 \pm 0.08$ & $13.15 \pm 2.66$ \\
$\mathrm{~T}_{2}$ & $4.95 \pm 0.13$ & $0.40 \pm 0.08$ & $12.84 \pm 3.07$ \\
$\mathrm{~T}_{3}$ & $4.48 \pm 0.13$ & $0.45 \pm 0.06$ & $10.09 \pm 1.50$ \\
$\mathrm{~T}_{4}$ & $4.43 \pm 0.15$ & $0.45 \pm 0.06$ & $9.96 \pm 1.39$ \\
$\mathrm{~T}_{5}$ & $4.48 \pm 0.10$ & $0.48 \pm 0.10$ & $9.71 \pm 1.92$ \\
$\mathrm{~F}$ & 28.1 & 0.77 & 2.4 \\
$\mathrm{P}$ & $0.000^{*}$ & 0.560 & 0.100 \\
\hline
\end{tabular}

F: one way ANOVA

$* \mathrm{P}<0.05$ (significant) 
Table 3. Effect of different sweeteners on the means of chemical composition of biscuits

\begin{tabular}{clclll}
\hline Treatment & Moisture (\%) & Protein (\%) & \multicolumn{1}{c}{ Fat $(\boldsymbol{\%})$} & Ash (\%) & Carbohydrate (\%) \\
\hline $\mathrm{T}_{1}$ & $3.17 \pm 0.52$ & $6.769 \pm 0.14$ & $17.95 \pm 2.76$ & $0.6 \pm 0.28$ & $71.51 \pm 4.32$ \\
$\mathrm{~T}_{2}$ & $4.53 \pm 0.31$ & $6.766 \pm 0.12$ & $17.65 \pm 5.14$ & $0.73 \pm 0.18$ & $70.32 \pm 6.98$ \\
$\mathrm{~T}_{3}$ & $4.27 \pm 0.08$ & $6.664 \pm 0.07$ & $16.9 \pm 2.77$ & $0.97 \pm 0.52$ & $70.196 \pm 4.05$ \\
$\mathrm{~T}_{4}$ & $4.23 \pm 0.35$ & $6.673 \pm 0.17$ & $17.13 \pm 1.76$ & $0.8 \pm 0.08$ & $70.17 \pm 2.84$ \\
$\mathrm{~T}_{5}$ & $4.16 \pm 0.43$ & $6.619 \pm 0.29$ & $17.15 \pm 0.43$ & $0.73 \pm 0.18$ & $71.34 \pm 1.51$ \\
$\mathrm{~F}$ & 0.15 & 0.29 & 0.08 & 0.43 & 0.02 \\
$\mathrm{P}$ & 0.120 & 0.873 & 0.987 & 0.786 & 0.999 \\
\hline
\end{tabular}

F: one way ANOVA

The chemical analysis of biscuits showed moisture content, crude protein, crude fat, ash content and carbohydrates content ranging from $3.17-4.53 \%, 6.619$ $-6.769 \%, 16.90-17.95 \%$ and $0.60-0.97 \%$ and 71.51 - 70.17\%, respectively. The results was inclose agreement with the results of Ahad, (1999) and Akbar, (2000) which revealed that moisture content, ash content, crude protein, crude fat, crude fiber and nitrogen free extract in cookies were ranging between $2.78-3.52 \%, 0.37-0.54 \%, 6.45-6.51 \%, 23.38-23.54 \%$, $0.08-0.13 \%$ and $6.603-6.670 \%$, respectively. These results are in agreement with the results of Pasha, et $\mathrm{al},(2002)$.

Sensory evaluation of biscuits: The biscuits prepared from different sweeteners were subjected to sensory evaluation for color, taste, odor, texture and after taste at $0,30,60$ and 90 days interval of storage in room temperature. Results pertaining to sensory evaluation of biscuits revealed that the color, odor, texture and after taste gave the best scores as follow: 4.6, 4.7, 4.8 and 5.0 , respectively in $T_{1}$ (sucrose) at 0 days of storage and the taste have its high score (4.8) after 30 days of storage, while the worst scores of taste, odor and texture were $2.8,2.8$ and 2.7 in $\mathrm{T}_{2}$ (fructose) after 90 and 30 days of storage.

The worst scores in color and after taste were 3.0 and 3.1 in $\mathrm{T}_{4}$ (mannitol) and in $\mathrm{T}_{3}$ (stevia), respectively after 60 and 90 days of storage. This result was in agreement with Rao, et al, (1995) which reported similar trend. They found that colour, taste, aroma, texture and overall acceptability of whole egg incorporated biscuits were adversely affected during six months storage in various packaging materials. Savita, et al, (2004) reported that stevia leaves in its powder form is green in color, 100-300 times sweeter than sucrose with after taste bitterness. It showed also ten products were tried at different levels of substitution i.e., $50 \%, 60 \%, 75 \%$ and $100 \%$. Product such as biscuits, grape juice, sweet bun, tea and milk shake were found to be accepted at $100 \%$ substitution to sugar.

This results were supported by Polyanskii, et al, (1997) which reported that stevia is used as sweeteners in dietetic foods, with particular reference being made to foods for diabetics. (Figure 1-5).

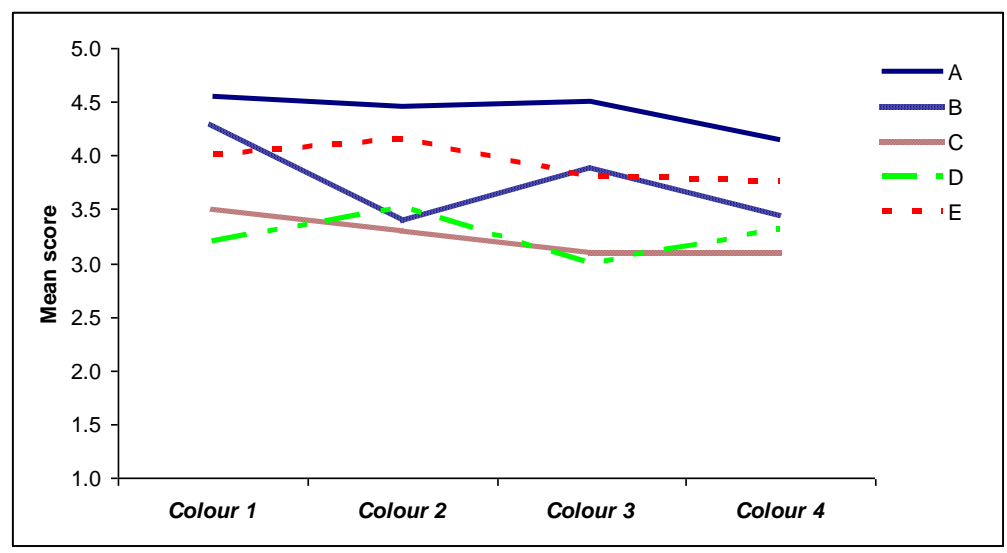

Fig. 1. Mean score of color in biscuits treated with different types of sweeteners at different time of storage

Where $\mathrm{A}=$ Sucrose treatment. $\mathrm{C}=$ Stevia treatment.

$\mathrm{E}=$ Sorbitol treatment.
$\mathrm{B}=$ Fructose treatment.

$\mathrm{D}=$ Mannitol treatment. 


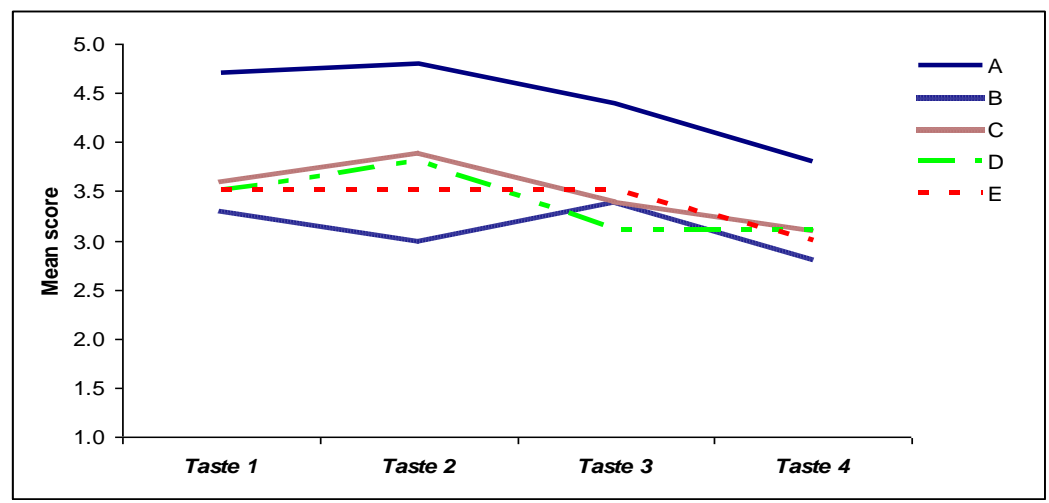

Fig. 2. Mean score of taste in biscuits treated with different types of sweeteners at different time of storage

Where $A=$ Sucrose treatment. $\mathrm{C}=$ Stevia treatment.

$\mathrm{B}=$ Fructose treatment.

$\mathrm{E}=$ Sorbitol treatment $\mathrm{D}=$ Mannitol treatment.

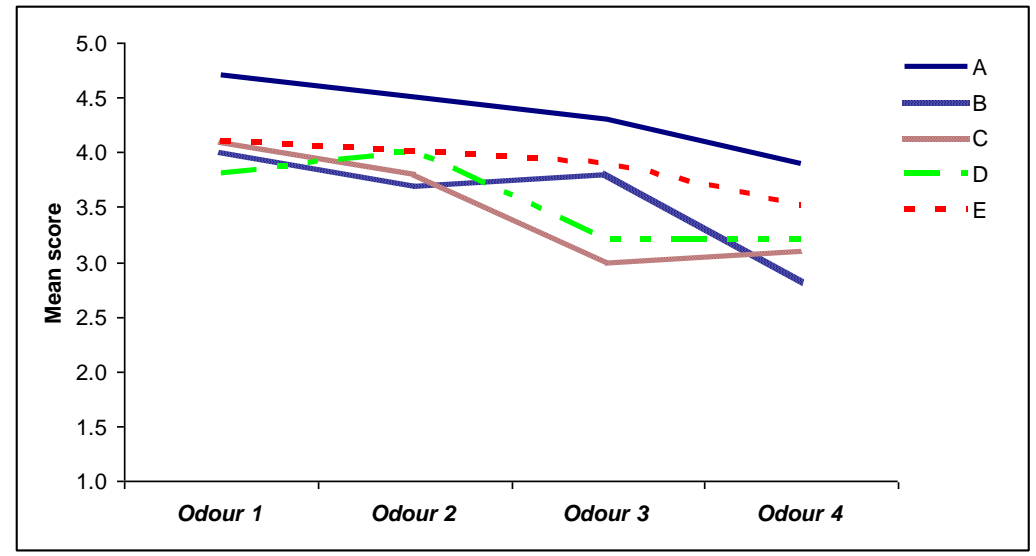

Fig. 3.Mean score of odor in biscuits treated with different types of sweeteners at different time of storage

Where A=Sucrose treatment.

$\mathrm{C}=$ Stevia treatment.

$\mathrm{B}=$ Fructose treatment.

$\mathrm{E}=$ Sorbitol treatment.

$\mathrm{D}=$ Mannitol treatment.

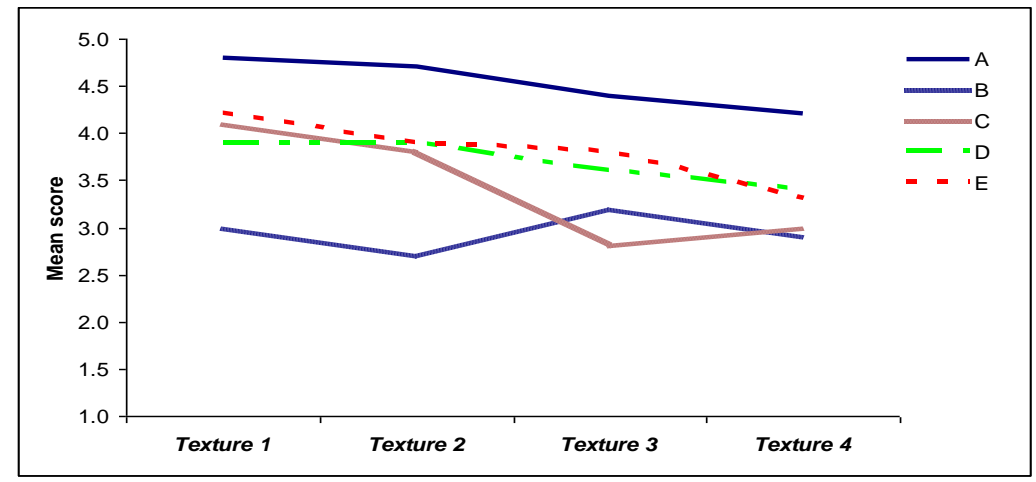

Fig. 4.Mean score of texture in biscuits treated with different types of sweeteners at different time of storage

Where $A=$ Sucrose treatment. $\mathrm{C}=$ Stevia treatment.

$\mathrm{B}=$ Fructose treatment.

$\mathrm{E}=$ Sorbitol treatment

$\mathrm{D}=$ Mannitol treatment. 


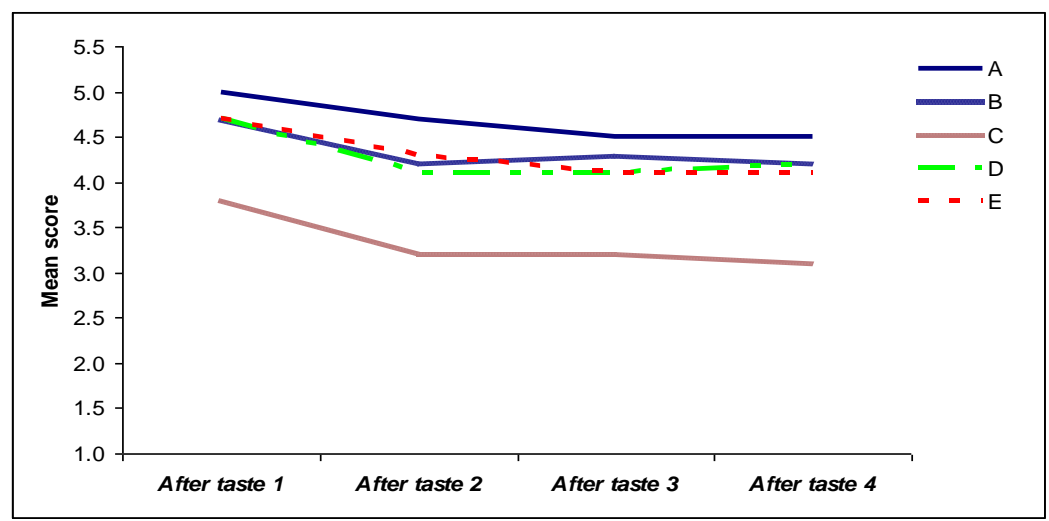

Fig. 5. Mean score of after taste in biscuits treated with different types of sweeteners at different time of storage

Where $\mathrm{A}=$ Sucrose treatment. $\quad \mathrm{B}=$ Fructose treatment.

$\mathrm{C}=$ Stevia treatment. $\quad \mathrm{D}=$ Mannitol treatment.

$\mathrm{E}=$ Sorbitol treatment.

Calorific value of biscuits: The calorific value of the biscuits prepared by the use of the different dietetic sweeteners has been presented in Table 4 . The results indicated that the calorific value reduced by the use of dietetic sweeteners. Highest calorific value (474.67 $\mathrm{Kcal} / 100 \mathrm{~g}$ ) was given by $\mathrm{T}_{1}$ (sucrose), while the lowest calorie $(459.54 \mathrm{Kcal} / 100 \mathrm{~g})$ was given by $\mathrm{T}_{3}$ (stevia). The results of this study are in close agreement with the findings of Siddique, (1995) who reported that increasing levels of artificial sweeteners in biscuits progressively decreased the calorific value of biscuits. (Figure 6).

\section{CONCLUSION}

Biscuits having $100 \%$ stevia gave less good quality biscuits in regard to after taste, while gave good quality biscuits in regard to calorific value. Replacement of sucrose by sorbitol gave good quality biscuits, while treatment of mannitol gave bad quality biscuits as regard to odor.

Table 4. Effect of different types of sweetener treatments of biscuits on the mean of energy value (Kcal/100g)

\begin{tabular}{cc}
\hline Treatment & Energy value (Kcal/100g) \\
\hline $\mathrm{T}_{1}$ & $474.67 \pm 13.70$ \\
$\mathrm{~T}_{2}$ & $467.19 \pm 29.20$ \\
$\mathrm{~T}_{3}$ & $459.54 \pm 14.60$ \\
$\mathrm{~T}_{4}$ & $461.54 \pm 8.70$ \\
$\mathrm{~T}_{5}$ & $466.19 \pm 0.21$ \\
$\mathrm{~F}$ & 0.14 \\
$\mathrm{P}$ & 0.962 \\
\hline
\end{tabular}

F: one way ANOVA

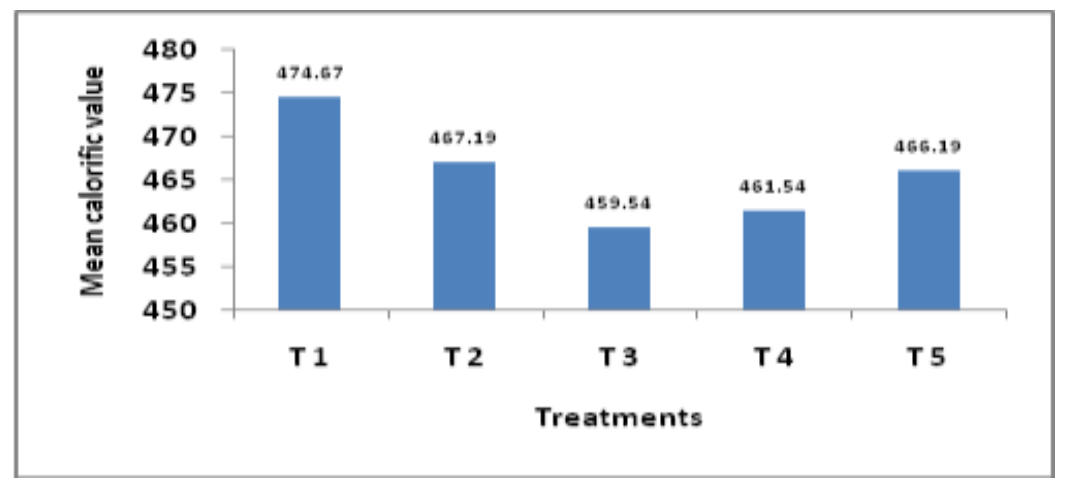

Fig. 6. Mean calorific value of biscuits treated with different types of sweeteners 


\section{REFERENCES}

AACC (American Association of Cereal Chemists), 2000. Approved Methods of American Association of Cereal Chemists 10th ed, AACC Inc: St Paul MN.

Ahad UJ. 1999. Preparation and quality evaluation of Biscuits containing potato flour. [M.Sc. Thesis]. Pakistan: Faisalabad University.

Akbar F. 2000. Nutritious cookies with the addition of peanuts. [M.Sc. Thesis]. Pakistan: Faisalabad University.

Alan T. 2002. Stevia, glycemic index and hypertension. Phytomedicin. 41: 9-14.

AOAC "Official Methods of Analysis" 1995. Association of Official Agriculture Chemist. Maryland, USA.

Butt MS, Imran P, Tufail F, Anjum FM. 2002. Use of low absorptive sweeteners in cakes. International Journal of Agriculture and Biology 4 (2): 249-51.

Causavin SP, Young LS. 2006. Current approaches to the classification of bakery products. Bakery products: science, technology and practice. Bake Tran, High Wycombe, Bucks, UK.

Curley LP, Hoseney RC. 1984. Effect of corn sweeteners on cookie quality. Cereal Chem 61: 274-8.

Ebbeling CB, Pawlak DB, Ludwig DS. 2002. Childhood obesity: Public- health crisis, common sense cure. Lancet 360: 473-82.

Egan H, Kirk RS, Sawyer R. 1981. Pearson's Chemical Analysis of Foods. Edinburg, London, Melbourne and New York: Churchilli Livingstone.

Francis F. 2000. Sweeteners: Nutritive Encyclopedia of Food Science. John Wiley and Sons, Inc New York 22444.

Ikan R. 1993. Natural glycosides as potential odorants and flavorants. Acta Horticulturae. (344): 17-28.

Manohar RS, Rao PH. 1997. Effect of sugars on the rheological characteristics of biscuit dough and quality of biscuits. J Sci Food Agric 75: 383-390.
Meilgaard, M.C., G.V. Civille and B.T. Carr. 2007. Sensory evaluation techniques 4th ed CRC Press LLC, New York.

Parpinello G, Versari A, Castellari M, Galassi S. 2001. Stevioside as a replacement of sources in peach juices: sensory evaluation. Journal of Sensory Studies. 16 (5): 471-484.

Pasha I, Butt MS, Anjum FM, Shehzadi N. 2002. Effect of dietetic sweeteners on the quality of cookies. Int J Agric Biology. 4: 245-8.

Polyanskii KK, Rodionova NS, Glagoleva LE. 1997. Stevia in cultured milk desserts for medical and prophylactic purposes. Molochnaya-promy-Shlennost. 5: 35.

Rao TS, Ramanuja MN, Ashok N, Vibhaker HS. 1995. Storage properties of whole egg powder incorporated biscuits. J Food Sci Tech. 32: 470-76.

Savita SM, Sheela K, Sunanda S, Shankar AG, Ramakrishna P, Sakey S. 2004. Health implication of stevia rebaudiana. J Hum Ecol. 15 (3): 191-4.

Shafiq M. 1999. Effect of different sweeteners on the quality of biscuits. [M.Sc. Thesis]. Pakistan: Faisalabad University.

Sharma N, Kaushal N, Chawla A, Mohan M. 2006. Stevia rebaudiana review. Agribios; 5: 46-48.

Siddique MA. 1995. Effect of artificial sweeteners on the quality of cakes and Biscuits. [M.Sc. Thesis]. Pakistan: Faisalabad University.

Strauss S. 1995. The perfect sweetener?.Technology Review; 98: $18-20$

Tanya T. 2006. Evaluation of the bulk sweeteners D-Tagatose and the high intensity sweetener splenda as sugar replacers in cookies. [PHD Thesis]. Alabama: Auburn university.

Warshaw H, Powers M. 1999. A search for answers about foods with polyols. The Diabetes Educator.; 25: 307-21.

Zarina M, Salim UR, Tahir Z, Amir J. 2010. Impact of xylitol replacement on physicochemical, sensory and microbial quality of cookies. Pakistan Journal of Nutrition. 9 (6):605-10. 


\title{
الملخص العربي
}

\section{تأثير المحليات المغذية والغير مغذية علي جودة البسكويت}

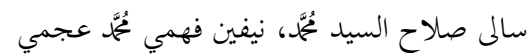

أجريت هذه الدراسة بهدف تقيم تأثير المحليات المغذية كالفركتوز، معاملة البسكويت بالسكروز، الفركتوز، الأستيفيا، مانيتول والسوربيتول

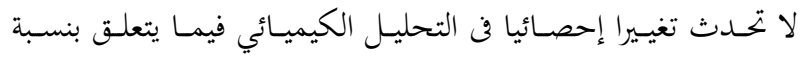

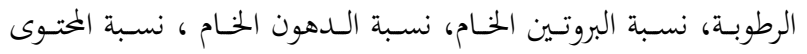

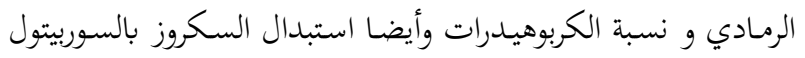

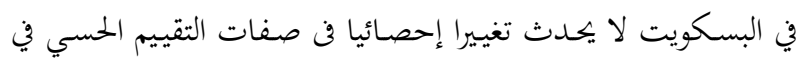

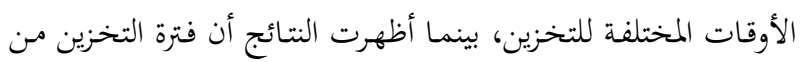

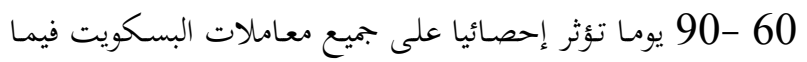

يتعلق بمتوسط درجة اللون والطعم والملمس والمرارة بعد الاكل، في حين

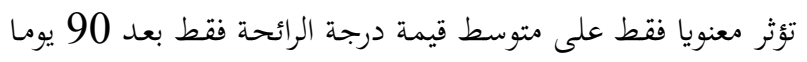

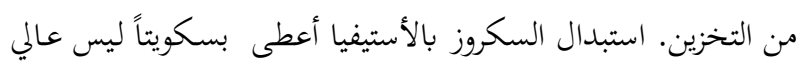

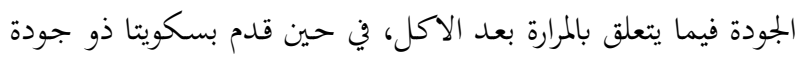

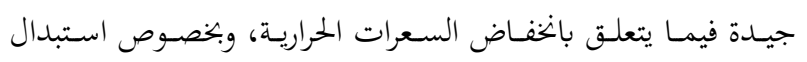

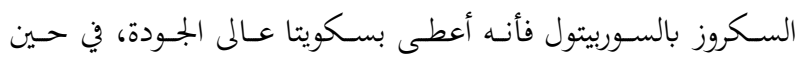

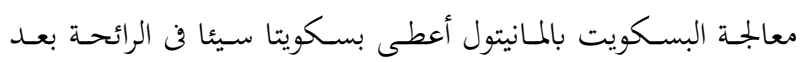
التخزين.

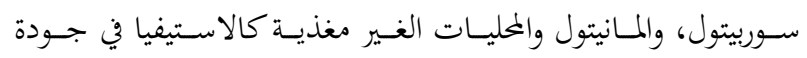
البسكويت عوضا عن السكروز، تم تصنيع البسكويت على نطاق شبه وله

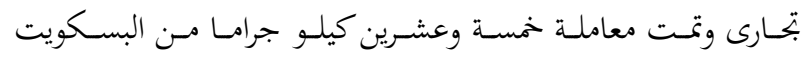

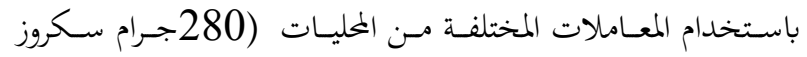

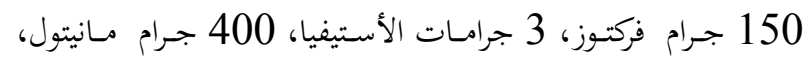

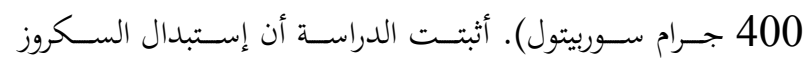

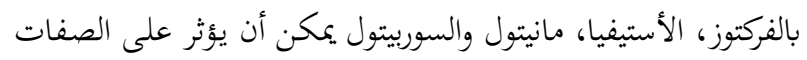

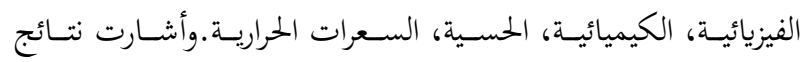

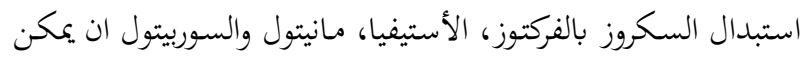
حدوث تغييرا إحصائيا على التحليل الفيزيائي للبسكويت فيما يتعلق الفئول بالقيمة المتوسطة للعرض (سم)، في حين يتأثر فقط معنويا على القيمة المتوسطة للسمك (سم) وعامل الانتشار (سم). 